\title{
HUMAN CAPITAL FROM THE VIEWPOINT OF CREATING COMPANY VALUE. CHALLENGES FOR FINANCIAL CONTROLLERS
}

\author{
Michal Chalastra \\ University of Gdansk, Gdansk, Poland \\ e-mail: michal.chalastra@ug.edu.pl \\ ORCID: 0000-0002-9993-1950
}

\section{Roman Kotapski}

Wrocław University of Economics, Wrocław, Poland e-mail: roman.kotapski@ue.wroc.pl ORCID: 0000-0002-7580-0059

\author{
Zuzana Kozubíková \\ University of Žilina, Žilina, Slovakia \\ e-mail: zuko@frcatel.fri.uniza.sk \\ ORCID: 0000-0002-4916-6090
}

\author{
Aleš Kozubík \\ University of Žilina, Žilina, Slovakia \\ e-mail: alesko@frcatel.fri.uniza.sk \\ ORCID: 0000-0001-6238-9494
}

(C) 2019 Michał Chalastra, Roman Kotapski, Zuzana Kozubíková, Aleš Kozubík

This is an open access article distributed under the Creative Commons Attribution-NonCommercial-NoDerivs license (http://creativecommons.org/licenses/by-nc-nd/3.0/)

DOI: $10.15611 / \mathrm{ms} .2019 .3 .01$

JEL Classification: M41, M120

\begin{abstract}
The research aim of this article is to look at human capital from the viewpoint of creating value for a company. In the era of the fourth industrial revolution (Industry 4.0), characterised by ever-increasing technological requirements, there is a demand for highlyqualified employees, including financial controllers, hence the key importance of their education and its scope. Knowledge limited to finance is not sufficient any more for future controllers since they will also have to have some orientation in the technology used by the company as well as its organization. As a result it will be necessary to implement a system of measuring the expenditure and the effects of creating intellectual capital in an enterprise. For these purposes it is possible to make use of the hard tools of controlling, such as budget, balanced chart of results, and the appropriate indicators for assessing this process.
\end{abstract}

Keywords: Industry 4.0, development and education of a financial controller.

\section{Introduction}

Value can be defined in various ways. The concept of value can be found in the theory of economics and in financial mathematics, where there are references to the value of money over time and the market value of a company, etc. The norm EN 13235-2014 Value Management means that value is a measure expressing a product or project which meets the requirements of the interested parties in respect of the used resources. By combining the principles and the methods of a value analysis with management actions, the space for managing value was created. This is an approach in which the creation of value is mostly concentrated on creating value for customers.

However, the current trend aims at orienting the process of creating value for all the interested parties (owners, customers, staff, suppliers, creditors, organs of the state, local administration, non-governmental organizations and the community). An enterprise, through its activity, has the possibility of influencing the process of creating value and increasing the degree of satisfying the needs of stakeholders, either decreasing the use of resources or using them in an optimal way (Ďurišová, 2017, p. 9). 
It is worth defining the way of measuring the growth of value. This is important because that process occurs in numerous different aspects of company's functioning. Individual units determine these areas according to their own needs, and in each of those, individual measures may exist. For this reason it is difficult to set one common parameter for measuring the growth of value for the company as a whole. An increase of financial results, the growing value of company shares and other similar synthetic financial parameters do not always reflect the actual growth of value, especially when measured over a long period of time. It is also difficult to compare the increase in value between various entities, therefore in each of the areas in which a given company creates an increase in value there should be identified suitable measures. Any change in values in the direction desired by the given company should be treated as an increase of value in a particular area (Ďurišová, Tokarčíková, and Kucharčíková, 2015, p. 221).

The creation of value can take place in many different areas, one of which is personnel, encompassing human capital. This is one of the elements of intellectual capital (Armstrong, 2002). It consists of resources and the flow of knowledge which the company has at its disposal. That knowledge can be classified as a non-material/intangible resource, which together with material resources constitutes the general value of an organization. Human capital means the knowledge, experience and skills of company employees, and it is highly important to acknowledge its vital role. Firstly, it contributes to a broadly interpreted increase in the efficiency of the currently used technologies. This, however, is an extensive growth, whereas intensive growth is of the utmost importance here. It is manifested by the spreading technological progress and such activities, owing to their innovativeness, generate high added value, which makes them especially desirable. This technological progress should be accompanied by the development of human capital.

The research aim of this article is to examine human capital from the viewpoint of creating value for a company in the era of the industrial revolution (Industry 4.0), in particular drawing attention to the requirements directed at controllers. For the purposes of this article the authors carried out the review of the literature and applied their conclusions from their own implementation of controlling systems within companies in various sectors of the economy. The authors also used their experience from lectures conducted for university students and management training during the training courses on cost accounting, managerial accounting, budgeting and controlling.

\section{Demand for highly-qualified personnel}

In the near future an increasing role will be played by IT systems combined with business processes. New smart systems of management will be autonomously assembling information received from various sources. Production will be carried out automatically with the use of robots controlled by these systems. IT systems will register and autonomously analyse vast amounts of data, and the role of employees in business processes will be much curtailed, and such examples can already be seen in practice. In Europe, Germany is the most advanced country in terms of modern technologies. It is the largest economy in the EU, providing excellent conditions for the functioning of a wide academic and technological base for the sector of advanced technologies. In this sector there already exist many renowned engineering companies which for a long time have been involved in planning the development of future smart factories (Kozubíková, 2016, p. 217).

Innovations enable companies to keep up with their competitors in the market place. From the viewpoint of creating value, highly-qualified employees play an ever-increasing role. Today, economically-developed countries do all that is feasible to retain their technological advantage. They try to implement the automatization of production process and robotics in industry as quickly as possible, and one of the reasons for this is the growing cost of labour and problems with employing highly-qualified personnel. Maintaining a leading position in the market definitely requires input from such employees. The World Economic Forum (Human Capital Report, 2015) published a ranking of ten countries with the largest percentage of highly qualified staff, which is shown in Table 1, and includes the following European states: Luxembourg, Switzerland, Sweden, Norway, Great Britain, and Holland.

Table 1. Ten countries with the highest percentage of highly-qualified staff

\begin{tabular}{|c|l|c|c|l|c|}
\hline No. & Country & $\begin{array}{c}\% \\
\text { of all } \\
\text { employees }\end{array}$ & No. & Country & $\begin{array}{c}\text { \% } \\
\text { of all } \\
\text { employees }\end{array}$ \\
\hline 1. & Luxembourg & 59.6 & 6. & Sweden & 49.1 \\
\hline 2. & Singapore & 54.7 & 7. & Norway & 48.8 \\
\hline 3. & Switzerland & 51.3 & 8. & Great Britain & 48.0 \\
\hline 4. & Israel & 49.7 & 9. & Holland & 47.5 \\
\hline 5. & Iceland & 49.2 & 10. & New Zealand & 47.4 \\
\hline
\end{tabular}

Source: World Economic Forum, 2015 / ILO Statistics (ILO). 
Robotics will totally change the established relation between the scale of production and the required human labour, and increasing production volume will no longer require the increased levels of employment. Innovations are gathering speed and have an ever-growing influence on the jobs market (Brynjolfsson and McAfee, 2014). All this brings about a fundamental change in access to human capital and results in the creation of new concepts that put an emphasis on high qualifications of employees.

\section{Requirements of the business sector regarding the education system}

Industry 4.0 is causing changes not only in the area of technological development but also within the enterprises themselves, which will need employees to create new technologies as well as the personnel capable of using them. Today the most sought-after are specialists with university-level education in technology and natural sciences, however, employing a good specialist in such a field is far from simple. Employers point to the small number of graduates from technical universities and the absence of their practical skills. This is also confirmed by press announcements and employment portals, as well as the opinions of managers. Another important problem in education is the degree to which the acquired academic knowledge actually matches the current state. Academic staff should be more involved in preparing and implementing technologies than has been the case so far.

Moreover, the last decade witnessed a significant drop in the number of students in technical disciplines throughout Europe. Ten years ago around one-third of all students studied in technical universities, while nowadays this figure is less than $20 \%$ in the majority of those countries. For this group of employees the educational process lasts several years, therefore we cannot expect changes in this trend in the short run.

Yet another problem is the fact that currently it is expected that technical education is combined with expertise in IT. Hence the demands posed by the business sector towards the system of education can be summed up as follows:

- improve the practical skills of university students,

- upgrade the teaching of IT subjects, mathematics, engineering, technology, mechanics and electronics,

- expand the scope of studies regarding management and finances.

During the course of implementing managerial accounting systems carried out by the authors in companies active in various sectors of the economy, it is possible to observe interest in the practical knowledge related to the calculation of the costs of ready-made products, services, and budgeting on the part of managers responsible for production, maintaining operations, as well as top management.

\section{Human capital from the viewpoint of creating value}

The above-described trends significantly alter the needs of the market in respect of employees. Nowadays most employers seek personnel with technical specialisation, and it is worth mentioning that this does not necessarily mean an academic degree in higher education. There is also a high demand for employees who are able to use and service modern machinery and equipment. Another category in demand, are employees with education in management, capable of utilising enormous amounts of data generated by modern IT systems of BI class. In both cases this should encompass both the theoretical knowledge acquired, for example during academic studies, and also the practical skills. These trends can lead to changes in the labour market, because Industry 4.0 significantly reduces the demand for labour, in particular where unqualified employees are concerned. Such a state of affairs can result in growing unemployment not only among the persons with a lower level of education, because the problem of finding work can also affect those with secondary or higher education. These changes may also become significant in their social aspect because it is highly probable that some people from the middle classes affected by technological unemployment will be unable to repay the previously contracted bank and mortgage loans (Kozubíková, 2016, p. 220).

Hence there have been ongoing changes in the principles of remuneration and motivation which are preferable to both employers and employees. Apart from the usual remuneration paid in financial form, there is a growing importance of other types of motivation. One of the more relevant motivational elements is the educational process offered nowadays by employers. In line with the described changes in the labour market, the direction of such an education should be aimed at increasing the competences of employees. This is beneficial for all sides: employers acquire staff capable of using modern equipment and managing vast amounts of data, employees acquire qualifications which increase their attractiveness in the jobs market, while society benefits by a decrease in numbers of people who have problems with finding employment. 
To sum up, the changes which are being brought by Industry 4.0 require an active approach to raising the level of professional qualifications.

\section{Future financial controllers and their education}

An example of the discussed changes is the evolution that has taken place in the requirements posed for financial controllers. The economic development has changed the role and tasks of a controller within a company. Since the 1990s controlling has evolved from the purely 'mechanical' processing of data to their creative usage. Financial controlling has its sources in the domains of accounting, economics and cost analysis, therefore the classification of the revenues and costs traditionally applied by controllers resulted from the broadly interpreted needs of external reporting. Thus, data were aggregated rather than referred to the vital individual resources of an enterprise such as technological lines, machines, channels of distribution, and management of human resources (Chalastra, 2015, pp. 94-104). That was thinking more of an accountant than a manager - a creator of information for the purposes of managing a company. Such a situation prevailed although there was already development in the knowledge on cost accounting which entailed a different way of thinking. During that time a financial controller, then still called a specialist in charge of economic affairs, mostly compiled reports concerning the realization of the budget. Such reports and analyses were characterised by their accountant-like approach, and were frequently incomprehensible and not very useful for management due to their hermetic language of accountancy. More advanced reports which concerned, for example, managing resources, the efficiency of machinery, were usually created in the domain of engineering and technical personnel.

The implementation of various systems of controlling such as budgeting or other tools of management accounting (for example a chart of results and KPI), required actual knowledge of the specificity of company operations by the accounts department staff or the existing specialists in charge of economic analyses, and not merely from the viewpoint of accounting but understanding the essence of the conducted business. This meant expanding the knowledge in terms of technological and technical aspects, organization of production, implementation of IT systems, management of projects such as the implementation of systems for e.g. controlling, as well as expertise in management. In this way, a specialist in economic analyses was slowly becoming a financial controller. Owing to their experience, financial controllers were often promoted to management posts, for example from managers of economic sections, chief accountants, financial directors and chairpersons. Their rise in status was accompanied by their increased responsibilities. It was not enough anymore to present simply a report on 'a plan and execution thereof' but it was also necessary to suggest a solution to a problem. The changing role of a controller in a company is described in an interesting way (Kilijański, 2017, pp. 21-23).

Yet even today technical personnel in many companies accuse employees of finance and accounts departments of notreally knowing what happens in their company. This also applies to at least some financial controllers, although often this is a result of the lack of communication between those departments and the technical sections. In the publication (Kotapski, 2014, pp. 303-304), the author points out that a specialist in controlling in a construction-building company, apart from a broadly interpreted knowledge on managerial accounting, has also to be an expert in this type of business activity, such as organization of a construction process, familiarity with different types of producers of concrete, transport and equipment, etc. Another published work (Controlling Process..., 2019, pp. 3741) draws attention to the fact that controllers closely cooperate with managers of various departments such as production, sales, etc. and therefore a controller without the actual knowledge about both the basic and supplementary processes within the company finds it difficult to practically implement and then use effectively the possibilities offered by controlling on different levels of managing a company.

The above changes have been also accompanied by technological change in the scope of managing the information which resulted from the fast development of 'economic' IT. First, there was the DOS system, then a spreadsheet that today is actually identified with EXCELL, followed by the systems of the ERP class. After the era of implementations and the 'embedding' of the ERP-class systems in enterprises, came the time for the systems of BI class. Currently one can observe the development of IT systems of the so-called Big Data. All this has increased the possibilities of data analysis as well as of creating reports which use a large variety of data, for example the raised positioning in a search engine, customer loyalty, 'likes', etc. We have vast amounts of data at our disposal and it is necessary to learn to use them, and IT systems simply allow us to realize our objectives. 
Changes in financial controller's work demand his/her continuous education, and not only in terms of finance but also increasingly in the areas of data analysis, knowledge of production technology and organization of the production process. Such education has to be augmented by the knowledge about available and new IT tools which alter the perception of controlling and stimulate the imagination over ways of its realization. One should not forget about the communication skills and the ability to negotiate with the people around either. This also implies tasks for the lecturers on controlling, who have to expand their knowledge on that subject all the time and combine the theory and practice, and who should also create standards in controlling (see Kotapski, 2012, pp. 119-134; Chalastra and Kotapski, 2018, pp. 36-42). Such expertise is best acquired during the implementations of controlling systems and meetings with other specialists at international and national conferences, as part of seminars on controlling and by gaining professional certificates from organizations such as CIMA and ACCA. However, it should be remembered that employing highly-qualified specialists as financial controllers comes at a certain cost, and therefore must be planned and included in a company budget.

\section{The ways of measuring expenditure and results in creating human capital}

The process of creating human capital, from the viewpoint of hard tools of accounting, is difficult in respect with the evaluation of its effectiveness since its results have to be compared with the incurred expenditure. Yet many items related to the financial outlay cannot be evaluated with precision and compared with each other because both the expenditure and its effects are measurable in different units of measure.

First, it is necessary to determine the objectives expected to be achieved in a given enterprise, for which the concept of a balanced chart of results may be useful. Due to the specificity of activities in every unit, the categories and values of these objectives should be set individually. In this case, we could assume as an objective the desired structure of employment, which can be quantified in respect of the age of employees, their period of employment, qualifications and the number of persons in relation to the company's size. An increase in human capital over a given period should mean a change of value in the parameters which constitute the objectives. However, the problem arises from the fact that these parameters concern different aspects. Therefore, it is difficult to compare them with each other.

The process of setting objectives should be supported by different types of strategic analyses, whose fundamental role is to establish the parameters expected in the future in respect of the company's own personnel and the prospective labour market. As a result, the entire process of planning the human capital growth will be based on realistic assumptions. Such analyses should involve the following issues:

- levels of remuneration and social benefits,

- scope of education realized within the company,

- availability of staff on the job market,

- demographic factors.

In the next stage, specific tasks should be set for realization with the aim of achieving the established objectives. For companies in which the process of creating human capital is seen as a relevant activity, this should be reflected in the company budget. This principle concerns a budget created with both a strategic and operational perspective. The following factors justify qualifying these actions within a strategic aspect:

- the long time necessary to achieve the planned changes,

- high expenditure,

- notable significance for the company.

The activities involved in creating human capital are very diversified because they are realized by many different units in an organization, and due to being scattered throughout its feature in the budgets of numerous sections. Thus, it is vital to identify the persons responsible for that process because the precise nomination of an employee who will be comprehensively responsible for that area of the company's functioning is a very important factor. Owing to this, it will be possible to create a consistent strategy to realize on the scale of a company as a whole (Chalastra, 2017, pp. 421-432).

In analyzing budgetary data it is necessary to summarize them appropriately in order to obtain comprehensive information about the entire process. Education realized in the company can be considered as one of the most important actions. Knowledge acquired by graduates of various types of schools and universities is often insufficient and not adapted to the specific functions of a given unit. For this reason it is necessary to continually expand the professional competences of employees. In this category an advantage is the possibility of defining the expenditure required to realize this objective, and it is relatively easy to set a budget and determine a variety of indicators describing the expenses incurred in reaching it (Chalastra, 2015, pp. 246-255). Yet 
determining the relation between such outlays and objectives is not so clear because it is difficult to establish dependencies between these two categories.

In referring to the actual data in order to establish the incurred expenditure, one should use the information available in the financial and accounting system. However, it should be noted here that the criteria of financial accounting do not allow for establishing the cost of creating human capital. In order to identify this, the system of accounting should be adjusted to the requirements of management accounting. One such modification is the appropriate expansion of book-keeping records, and the best results are obtained by introducing additional dimensions of the classification of costs. At the same time, it is not necessary to introduce more details into the existing dimensions used by financial accounting. This results from the fact that identifying costs linked to creating human capital is not required in financial accounting, and doing so could cause the following problems:

- excessive and unwarranted expansion of the financial accounting system,

- no possibility of obtaining full data concerning these actions.

The records on the appropriate dimensions of primary data on costs allow only to establish the direct ones (Chalastra, 2018, p. 66). Another, complementary way of obtaining information about the costs incurred due to implementing actions aimed at creating the development of human capital are the calculation tools, and the recommended methods are based on accounting costs of the actions of $\mathrm{ABC}$. At the same time, the techniques of the so-called traditional cost accounting should not be applied for this purpose. Thanks to the calculation tools, it is possible to apply the method of full cost accounting to identify the value of the analyzed expenditure which allows to include in this category, among others, the justifiable part of the costs connected with maintaining the units realizing activities aimed at creating human capital.

\section{Conclusions}

Creating company value is concentrated mostly on creating value for customers. An enterprise can influence value by increasingly satisfying the needs of stakeholders. In this article the authors focused on human capital, employees and their impact on the increase of value in Industry 4.0, and pointed out the ongoing shortage of the workforce with technical education.

The development of the economy also brings change and expands the role played by a financial controller in a company. He/she has to continuously keep up with changes, especially in respect of the knowledge regarding the company in which, or for which, he/she works. Therefore, a financial controller has to develop all the time and improve his/her qualifications, hence the expenses incurred for this development in the form of training seminars, post-graduate studies and obtaining certificates, as well as the expenses related to the use of the continually developed and perfected IT tools to support controlling.

Human capital is playing an ever-greater role, and because of this the process of creating it should be subject to a conscious action with a strategic and operational perspective. It would be good to use for this purpose the hard tools of controlling, among them balanced charts of results, strategic analyses, strategic scenarios, project management, budgeting and the extended records of accounting data including the requirements of management accounting.

\section{References}

Armstrong, M. (2002). Řizení lidských zdrojů. 1. vyd. Praha: Grada Publishing.

Brynjolfsson, E., and McAfee, A., (2014). The Second Machine Age. First Edition. New York: Norton \& Company, Inc.

Chalastra, M. (2015). Zakres integracji rachunku kosztów tworzonego na potrzeby systemów rachunkowości finansowej i budżetowania - wyniki badań empirycznych. Prace Naukowe Uniwersytetu Ekonomicznego we Wrocławiu, (398).

Chalastra, M. (2015). Identification of good education practices in the field of management accounting - presentation of results of empirical research conducted in companies in Poland. In Knowledge for Market Use 2015. Olomouc: Department of Applied Economics Palacky University Olomouc.

Chalastra, M. (2017). Strategic and operational perspective of the principles of identification of the scopes of responsibility for costs. In D. Procházka (Ed.), The impact of globalization on international finance and accounting. Cham: Springer Proceeding in Business and Economics.

Chalastra, M. (2018). Rachunek kosztów księgowego i controlle$r a$. Wrocław: Wydawnictwo MARINA.

Chalastra, M., and Kotapski, R. (2018). Is it time to audit controlling? In P. Slavičkova, T. Talášek (Eds.), Knowledge for Market Use 2018: Public Finances in the Background of Sustainable Development. Olomouc: Palacky University Olomouc.

Ďurišová, M. (2017). Hodnota a jej vyjadrenie v podniku. Žilina: EDIS vydavatel'ské centrum ŽU.

Ďurišová, M., Tokarčíková, E., and Kucharčíková, A. (2015). The decomposition of the result of the business transformation process in the value terms. In Procedia - Economics and Finance, (30, pp. 213-225).

International Labour Organization: Global Wage Report. (2014/15). Retrieved from http://www.ilo.org/global/about-the-ilo/newsroom/news/WCMS_324645/lang--en/index.htm.

Kilijański, W. (2017), Węęrówka działu controllingu po strukturze organizacyjnej, Controlling i Zarządzanie, 4(18).

Kotapski, R. (2012). Nauka i praktyka a dydaktyka. In A. Kardasz (Ed.), Doktor niejedno ma imię, Wrocław: Wydawnictwo Uniwersytetu Ekonomicznego we Wrocławiu. 
Kotapski, R. (2014). Budżetowanie w zarządzaniu w przedsiębiorstwie budowlano-montażowym. Wrocław: Wydawnictwo MARINA.

Kozubíková, Z. (2015), Finančná gramotnost' ako významný ciel' ekonomického vzdelávania. In P. Slavičkova, J. Tomčik (Eds.), In Knowledge for Market Use 2015. Olomouc: Department of Applied Economics Palacky University Olomouc.

Kozubíková, Z. (2016), The 4th industrial revolution: a challenge for the education system. In International Conference on In- formatization of Economic and Management Processes: Proceedings, 15th September (pp. 217-222). Brno: B.I.B.S.

Möller, K. (Ed.). (2019). Controlling Process Model 2.0. A Guideline for Describing and Designing Controlling Processes. Poznań: Akademia Controllingu.

World Economic Forum. (2015). Top 10 countries with the largest share of people in high-skilled employment. Retrieved from https://www.weforum.org/agenda/2015/08/which-countrieshave-most-high-skilled-workers/.

\section{KAPITAL LUDZKI Z PUNKTU WIDZENIA TWORZENIA WARTOŚCI DLA PRZEDSIĘBIORSTWA. WYZWANIA DLA CONTROLLERÓW}

Streszczenie: Celem badawczym niniejszego artykułu jest spojrzenie na kapitał ludzki z punktu widzenia tworzenia wartości dla przedsiębiorstwa. W dobie czwartej rewolucji przemysłowej (Przemysł 4.0), charakteryzującej się między innymi coraz to większymi wymaganiami technologicznymi, występuje zapotrzebowanie na wysoko wykwalifikowanych pracowników, w tym controllerów. Edukacja controllera i jej zakres stają się zatem kluczowe.. Wiedza ograniczona tylko do finansów nie będzie wystarczająca dla controllera przyszłości. Musi on również orientować się w technologii stosowanej w przedsiębiorstwie czy też w jego organizacji. Z tego powodu konieczne będzie wdrażanie systemu pomiaru nakładów i efektów tworzenia kapitału intelektualnego w przedsiębiorstwie. W tym celu można wykorzystać twarde narzędzia controllingu, jak: budżet, zrównoważona karta wyników czy też odpowiednie wskaźniki oceny.

Słowa kluczowe: Przemysł 4.0, rozwój i edukacja controllera. 